\title{
Factors influencing rural household attitude towards solar home system in Ethiopia
}

\author{
Asmare Mossie Zeru ${ }^{1, *}$ (D) and Dawit Diriba Guta ${ }^{2}$ \\ ${ }^{1}$ Federal Technical and Vocational Education and Training Agency, Addis Ababa, Ethiopia \\ 2 Center for Environment and Development Studies, College of Development Studies, Addis Ababa University, Addis Ababa, \\ Ethiopia
}

Received: 9 July 2021 / Received in final form: 17 October 2021 / Accepted: 17 October 2021

\begin{abstract}
Solar home system is a promising energy option for households living in off-grid areas of developing countries. However, household inclination towards consuming such clean energy is hampered by numerous factors. This study is motivated by the absence of more in-depth empirical studies on factors determining households' attitudes towards using SHS. By filling this gap, this study intends to generate informed policy recommendations. For this purpose, we used data generated from 228 adopted and 143 non-adopted households living in Basoliben district, northern Ethiopia by applying mixed data collection approaches. The ordered logistic regression model was employed to estimate factors influencing households' attitudes towards SHS. The findings reveal that being male household heads is $2.6 \%$ and $3.2 \%$ more likely to have unfavorable and neutral attitudes respectively and $5.9 \%$ less likely favorable attitudes towards SHS. As income increase by one Birr, households are about $8.2 \%$ more likely to have a favorable attitude towards SHS, and $3.8 \%$ and $4.4 \%$ less likely to have unfavorable and neutral attitudes towards SHS respectively. Households having a cell phone are $3 \%$ and $5.5 \%$ less likely to be in the unfavorable and neutral attitude category respectively and $8.5 \%$ more likely to be in the favorable attitude category. Likewise being accessed with media is $4.2 \%$ and $6.9 \%$ less likely they have unfavorable and neutral attitudes respectively, and $11 \%$ more likely they have a favorable attitude towards SHS. Moreover, households who attained training are $3 \%$ and $5 \%$ less likely they have unfavorable and neutral attitudes respectively, and are $8 \%$ more likely to have a favorable attitude towards SHS. The finding of this study suggests that improving the economic status of households, better media access, and training would play a crucial role in creating a positive attitude within rural households to increase the adoption of SHS in rural Ethiopia.
\end{abstract}

\section{Introduction}

Globally, the number of people living without electricity access dropped from almost one billion in 2017 to 860 million in the latest estimate of 2018. Close to 600 million people, which represents more than two-thirds of the global total, are from Sub-Saharan Africa [1]. According to the 2018 data of IEA, about half of theSub-Saharan Africa population living without electricity access is from five countries; namely Nigeria, the Democratic Republic of Congo, Ethiopia, and Uganda.

In developing countries, solar photovoltaic (PV) has got the potential to be an alternative source of clean energy at the household level [2]. Similar to developed countries, many developing countries in Asia, Africa, and South America are emphasizing the inclusion of solar power in their energy mix to lessen the burden on non-renewable and

\footnotetext{
* e-mail: asmare410@gmail.com
}

expensive sources of energy [3]. In Africa, rapid progress has been seen in the propensity of using SHS. For instance, Ethiopia, Kenya, and Tanzania accounted a significant number of people gaining access to new SHS in 2018 [1].

Renewable energy and energy efficiency are key to sustainable development, enabling energy access, spurring economic growth, creating employment, and improving health [4,5]. To address the energy crisis of poor households in developing countries, off-grid solutions including solar home systems, solar lighting, and increasingly mini-grids are decisive [6].

Even though Solar Home System (SHS) has a high upfront cost, it has been considered as an attractive alternative energy source for households located in off-grid areas of many developing countries due to its cleanness, and simplicity to use [7]. Green innovations such as solar have the potential to lower fossil fuel dependency and minimize carbon emissions. But introducing such kinds of energy technology in developing countries requires financial and educational support [8]. 
Perceptions and attitudes are important factors that influence consumer behavior and innovation adoption. Perception is the process by which individuals make sense of sensations utilizing their sensory receptors, whereas attitude is the way that an individual views, or behaves towards an object, often in an evaluative way [9]. A Positive attitude and correct perception towards any technology or innovation are the foundation pillars that determine its adoption rate [10]. Therefore, analysis of perceptions can be used to assess the rate of adoption, and time preferences for products [11]. Similarly, Auty and Elliott [12] confirmed that understanding the attitudes of consumers towards an innovative product has two key benefits. The first one is to identify and effectively manage the strengths and weaknesses of the attributes of the innovation. The second benefit is that to make the innovation attractive, more control over the marketing strategy can be imposed.

Many scholars have investigated households' attitudes and perceptions toward the use of SHS. For instance, regarding attitudes, Faiers and Neame [13] in the UK, and Sun and Spicer [14] in China conducted studies on residents' attitudes towards solar PV systems. Tsaur and Lin [15] in Taiwan also explored customers' attitudes towards building attached solar PV equipment using the technology acceptance model. Likewise, Alrashoud and Tokimatsu [16] in Saudi Arabia also studied factors influencing the social perception of residential solar PV systems. Moreover, Yadav et al. [10] investigated both the perception and attitude of rural women towards solar in India.

However, there are limited studies in most of the developing countries regarding what factors determining the attitude of households whether to adopt or reject SHS, particularly in Ethiopia. For instance, in Africa, many scholars such as Adepoju [17] [Nigeria], Gitone [18], Keririr [19], and Naomi [20] [Kenya] are only concerned with determinants that hinder the adoption of solar energy in a general manner. Likewise in Ethiopia, Mekuria [21], Guta [22], Anteneh [23], and Zeru and Guta [24] studied determinants of solar energy adoption.

Although there is a growing interest in investigating the determinants of solar energy technology adoption, in a general manner, there are limited studies on the factors influencing household attitudes towards solar home systems. Since solar is infant technology in rural Ethiopia, it is imperative to study households' attitudes towards using SHS and factors dictating it to give informed policy recommendations. Focusing on these factors policymakers promote acceptance of the technology within the rural community.

Therefore, the main purpose of this study was to investigate factors affecting the attitude of households towards SHS using ordered logistic regression. The result of the study will have a vital role in developing programs and policy formulation by providing current and valuable evidence for promoting the adoption and use of the solar home system and other renewable energy technologies in rural Ethiopia.

\section{Literature review}

\subsection{Theoretical literature}

\subsubsection{Theory of reasoned action}

The theory of reasoned action proposed that rational thought grounds human behavior [25]. The model uses the Principle of compatibility, which predicts human attitudes that reflect behavior only to the extent of the same valued outcome state of being (evaluative disposition) [26]. According to the theory, behavioral intention is determined by attitude and subjective norm, of which either attitude or subjective norm might be the most important determinant of any particular behavior of peoples to act such as adopting and using new technology including solar energy. Generally, an increase in subjective norms and attitude helps to have a strong desire to perform the behavior.

Attitude is defined as a favorable or unfavorable feeling of an individual to perform a specific action. An individual wants to perform a specific behavior after he or she knows or evaluates either the positive or negative consequences of the behavior [27]. Based on this theory, this paper addresses how households feel either to use or reject SHS. Figure 1 shows the theory of reasoned action model developed by Ajzen and Fishbein (1980).

\subsubsection{Innovation diffusion theory}

Innovation diffusion is a process in which there are channels through which communication between members of a social system is being undertaken. It was developed by the sociologist and communication theorist Everett Rogers [28]. Rogers defined innovation as "an idea, practice or objects perceived as new by an individual or other unit of adoption". He also defined diffusion as a process by which innovation is communicated over time among participants of a social system through certain channels [29]. The innovation diffusion theory suggests that the technology adoption behavior of an individual is determined by his or her perceptions regarding relative advantage, compatibility, complexity, and observability of an innovation that influences the rate of innovation adoption. It sets out the practical adoption process, in that the speed at which an adopter passes along this process is influenced by the attributes of particular Innovations, and the adopter's propensity to accept innovation. According to Rogers four elements including social system, innovation itself, timing, and communication channels could affect the diffusion of innovations. In this context, communication or interpersonal exchange of information is more powerful in convincing a social system to accept a new technology such as solar. Based on this the paper tried to address related factors affecting households' attitudes towards SHS. Figure 2 below illustrates the innovation diffusion theory developed by Rogers in 1995. 


\subsection{Empirical literature review}

The attitude of households towards solar energy technology might affect their adoption intensity. Household heads who have a neutral attitude needed to be motivated to change their attitude towards the favorable side then can be scaled up the expansion of renewable energy sources for rural households in minimizing reliance on biomass energy sources ultimately can reduce deforestation [30]. A study conducted in California found that peer-effect, personal attitude/values, and favorable subsidies have influenced the willingness to adopt solar PV technology [31].

Previous works of literature explained the intention to act in favor of or against new sustainable energy technologies, which is influenced by attitude, social norms, perceived behavioral control, and personal norms [32]. Attitude is influenced by the perceived costs, risks, and benefits, positive and negative feelings in response to technology, trust, procedural fairness, and distributive fairness. Besides, Chen [33] also confirmed that the attitude of the household towards innovation affects solar PV adoption. Likewise, Sun and Spicer [14] identified household's concerns and attitudes about purchasing solar PV systems in China. Moreover, a previous study suggested

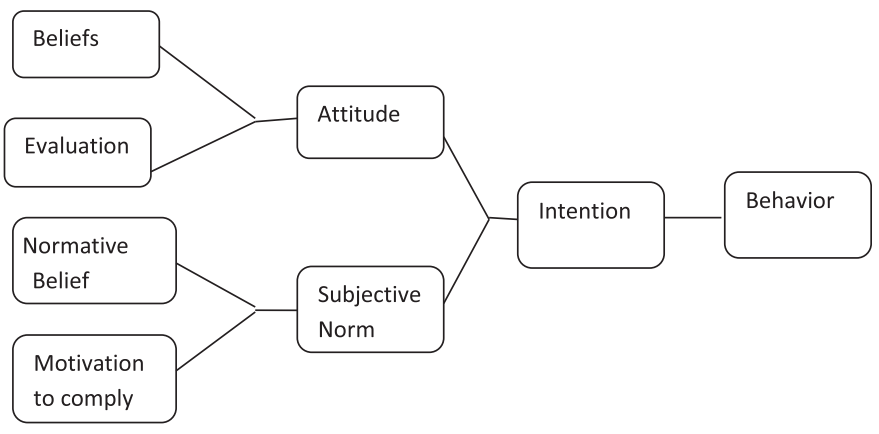

Fig. 1. Theory of reasoned action (Adopted from Ajzen \& Fishbein, 1980). that in developing countries, a low level of awareness about technology is considered a critical problem, which misleads the transmission of information among individuals about the advantage of the technology [34].

Faiers and Neame [13] used an innovation diffusion theory to investigate households' attitudes towards system attributes of the solar system and also identified barriers that prevent adopting technology in the UK. Similarly, research conducted in Saudi Arabia revealed factors that potentially motivate or impede the social perception of residential solar photovoltaic based on innovation diffusion theory [16]. Furthermore, Yadav et al. [10] explored both perceptions and attitudes of rural women towards solar cookers in India. The author revealed that a positive attitude and correct perception towards any technology or innovation are the foundation pillars that determine its adoption rate. Previous literature argued about how the income level of households could have a considerable influence on their plan intend to do in the future. For instance, Yadama and Sherraden [35] revealed that the income of households leads to more positive attitudes and behavior to perform a specific plan.

Kaplan and Haenlein [36] portrayed social media as the environment in which social networking takes place and has changed the way that customers follow to gather new information and make their own decisions. Likewise, previous literature elucidated the role of media in attitudinal change. In that, individuals with less positive attitudes towards technology might be persuaded using various methods including media (television radio) [37].

Many of the above-reviewed pieces of literature are mainly concerned with households' attitudes and perceptions towards solar energy technology. But the important limiting and driving factors behind their attitude towards SHS have not been explored. Therefore, this motivated the researchers to investigate factors affecting households' attitudes towards SHS using empirical evidences.

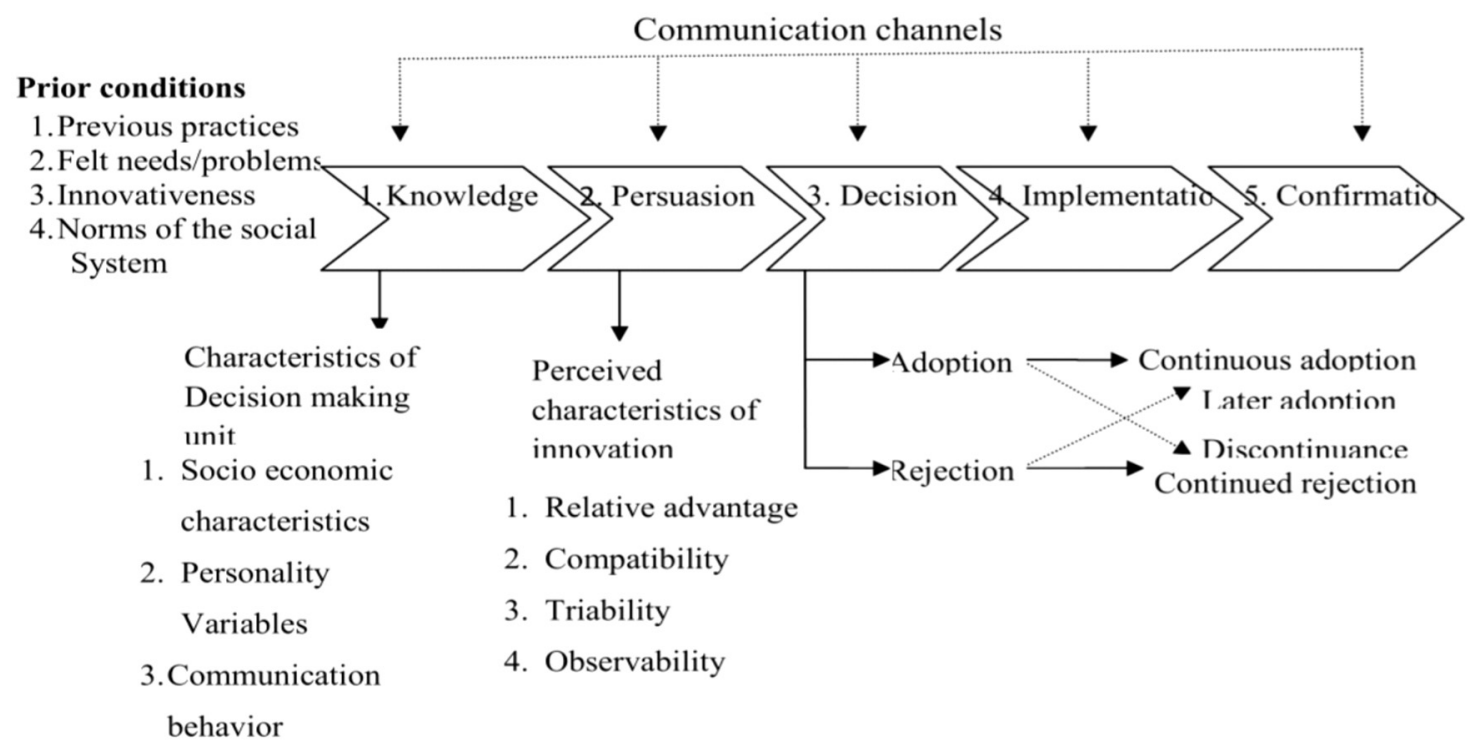

Fig. 2. Innovation diffusion theory (Adopted from Rogers, 1995). 


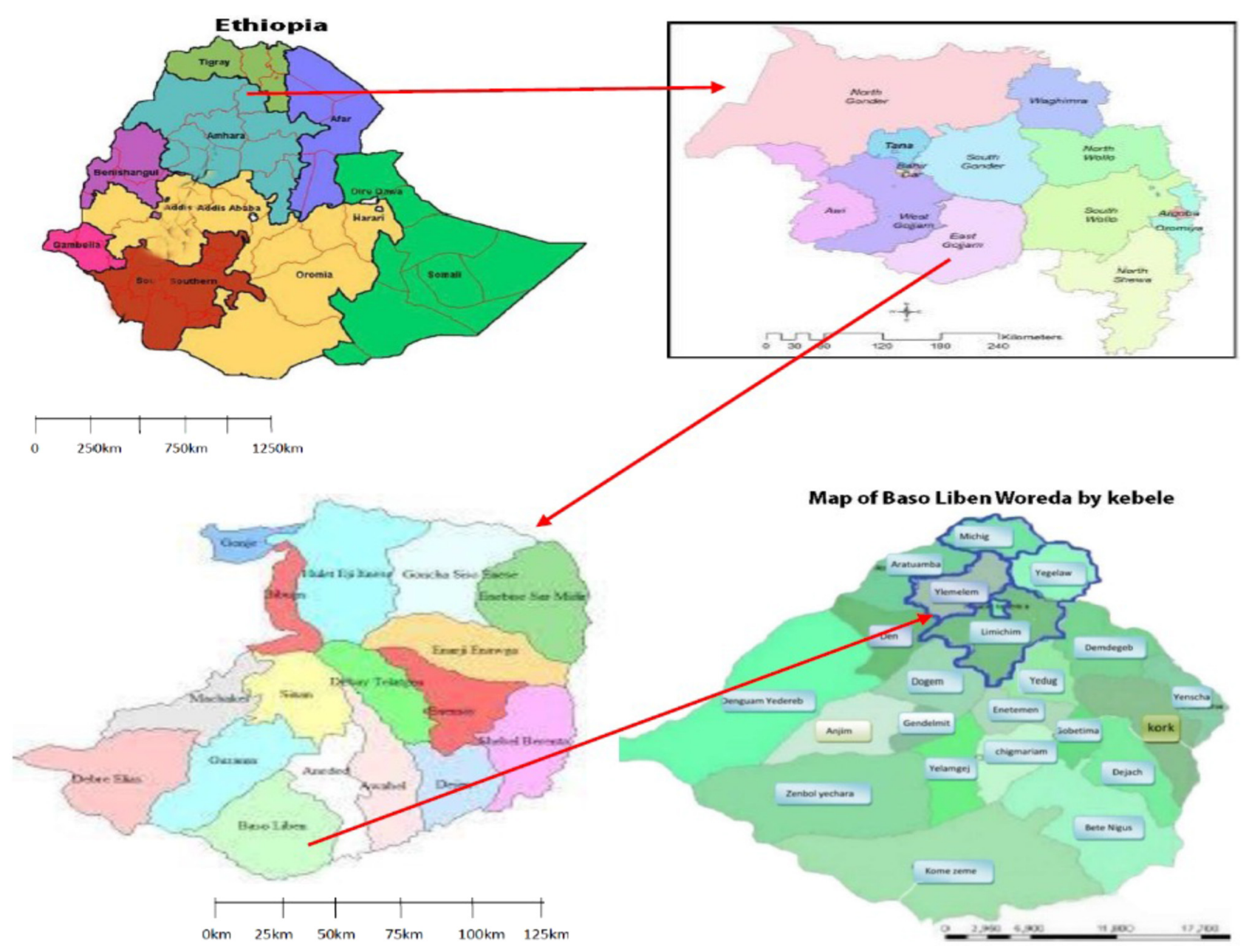

Fig. 3. Map of the study area (Adopted from Baso Liben woreda, 2020).

\section{Method and data}

\subsection{Study area}

The study was focused on four kebeles ${ }^{1}$ of the Baso Liben district in East Gojjam Zone of the Amhara region, northern Ethiopia. It is $307 \mathrm{~km}$ far from Addis Ababa, the capital city of Ethiopia and 292, and $27 \mathrm{~km}$ from regional city Bahir Dar and Debre Markos (Zone capital town) respectively. The district is bordered on the south by a bend of Abay (Blue Nile) river which separates it from the Oromia region, on the northeast by Aneded, and on the North West by Gozamin districts. It has two agro-ecological zones of woyna dega $(46 \%)$ and kola (54\%) with a total area of 113,284 hectares. It is characterized by hilly (35\%), flat topography (30), mountain $(25 \%)$, and valley (10\%). The annual rainfall of the district ranges from $900 \mathrm{~mm}$ to $1200 \mathrm{~mm}$, and temperature ranges from 15 to $25{ }^{\circ} \mathrm{C}$. The total population of the district is 170,387 , distributed in 22 rural and 4murban and semi-urban kebeles. Of which the number of men and women accounts $47.4 \%$ and $52.6 \%$ respectively. Out of the

\footnotetext{
${ }^{1}$ Kebele: The lowest administrative unit in Ethiopia, which made up of several villages.
}

total population of the district, only $7.9 \%$ of the population is urban residents and the majority (92.1\%) is rural settlers. The Figure 3 shows the map where the study was conducted.

\subsection{Data and sampling}

A mixed research design was employed in this study. The data was collected from four kebeles of the district, namely; Yelemelem, Yegelaw, Limichim, and Michig. The kebeles were purposively selected based on infrastructural accessibility, high adoption intensity, time, and other physical factors. 371 Sample households were randomly selected proportionately from both adopted and non-adopted households living in the selected kebeles. Of which 228 were adopted (55 from Yelemelem, 52 from Yegelaw, 37 from Michig, and 84 from Limichim) and 143 were non adopted households (41 from Yelemelem, 6 from Yegelaw, 37 from Michig, and 59 from Limichim kebeles). Besides, 12 key informant interviewees had also participated in qualitative data. Relevant data concerning factors affecting households' attitudes towards SHS were collected using both structured and semi-structured data collection tools from February 02 and March 06/2020 by four enumerators. 
The enumerators were oriented before starting the data collection and also closely supervised during data collection by the researcher. The survey questionnaires included the socioeconomic variables, demographic characteristics, utilization of SHS, reasons to use or reject SHS, households' attitudes towards SHS, and other pertinent variables.

\subsection{Empirical model}

The ordinal logistic regression model is commonly used to determine factors influencing attitudes towards technologies. It is the extension of logistic regression applied to dependent variables having more than two (ordered) response categories. The model applies to the data that meets the proportional odd assumption. We use ordinal logistic regression when the dependent variable is categorical and the explanatory variables are either continuous or categorical [38]. Both ordered logistic and probit models are classified under generalized linear regression models and commonly used to analyze data that has ordinal response variables /ordered scores/ which have a natural ordering way among levels (such as unfavorable, neutral, favorable). Moreover, the other literature stated that ordinal regression (either logistic or probit) is used to model the association between response variables and a set of explanatory variables [39].

In this study, the researcher used ordered logistic regression to determine factors affecting the attitude of the household towards the solar home system. Ordered logistic regression is chosen for this study other than ordered probit because of its simplicity to compute and has also been widely used in similar studies. Oluoch et al. [40] used ordinal logistic regression to determine public awareness, acceptance, and attitude towards renewable energy in Kenya. Other studies such as Hagen and Pijawka [41], Karytsas et al. [42] also applied ordered logistic regression on similar issues.

The dependent variables (ratings) in this study are supposed to range from unfavorable (1) to favorable (3). The attitude parameter was used as a dependent variable while the independent variables / predictors/ were the gender of the head, age of head, family size, education level of the head, off-farm income participation, log income, landholding size, number of cattle (TLU), credit access, house type, mobile cell phone, media access, and training access.

According to Cameron and Trivedi [43], the probability of a respondent $(i)$ to select an alternative $j$ in $1,2,3 \ldots, j-1$ can be modeled as follows:

Let us consider $\mathrm{y}^{*}$ an index model with a latent variable representing a starting point:

$$
y_{i}^{*}=x^{\prime}{ }_{i} \beta+u_{i}
$$

For an $m$-alternative ordered model we define:

$$
Y_{i}=j \text { if } \alpha_{j-1}<y_{i}^{*} \leq \alpha_{j}
$$

where $\alpha_{0}=-\infty$ and $\alpha_{m}=\infty$, then

$$
\begin{aligned}
\operatorname{Pr}\left[y_{i=j}\right] & =\operatorname{Pr}\left[\alpha_{j-1}<y_{i}^{*} \leq \alpha_{j}\right] \\
& =\operatorname{Pr}\left[\alpha_{j-1}<x^{\prime} \beta+u_{i} \leq \alpha_{j}\right] \\
& =\operatorname{Pr}\left[\alpha_{j-1}-x^{\prime}{ }_{i} \beta<u_{i} \leq \alpha_{j}-x^{\prime}{ }_{i} \beta\right] \\
& =\mathrm{F}\left(\alpha_{j}-x^{\prime}{ }_{i} \beta\right)-\mathrm{F}\left(\alpha_{j-1}-x^{\prime}{ }_{i} \beta\right),
\end{aligned}
$$

where $y$ represents one of the dependent variables, $j$ represents alternatives for a particular $y, \alpha_{j}$ represents the thresholds between alternatives, $x_{i}$ is a vector holding the regressors. For the ordered logit model, $u$ is logistic distribution with logistic function, $F(z)=e^{z} /\left(1+e^{z}\right)$.

The marginal effects for the expression (3) are given by [43].

$$
\begin{aligned}
\text { Marginal effect } & =\frac{\partial \operatorname{Pr}\left[y_{i=j}\right]}{\partial x_{i}} \\
& =\left\{F^{\prime}\left(\alpha_{j-1}-x^{\prime}{ }_{i} \beta\right)-F^{\prime}\left(\alpha_{j}-x^{\prime}{ }_{i} \beta\right)\right\} \beta
\end{aligned}
$$

where $F^{\prime}$ signifies the derivative of $F$, which indicates the probability of selecting $j$ alternatives as $x_{i}$ increased by one unit.

\section{Result and discussion}

\subsection{Descriptive statistics}

Table 1 presents the descriptive statistics of explanatory variables. The analysis shows that about $91 \%$ of households were male-headed and $9 \%$ were female-headed. The average age of household heads was 49.69 years. The average family size of sample households was 4.91. The main income source of the community in the area is mixed agriculture (both livestock and crop production). About $9 \%$ of the sample household participated in off-farm income-generating activities. The average landholding size of the households was 1.49 ha. Likewise, the average number of cattle of households was 3.4 (in Tropical Livestock Unit ${ }^{2}$ ). The majority (96\%) of sample households have the opportunity to get credit services. About $51 \%$ of sample household heads have their mobile cell phone. Similarly, $82 \%$ of sample households have access to media (either radio or TV). Among sample household heads, $55 \%$ got awareness creation training regarding the solar home system. The average annual income of sample households was 80,171.7 Birr. As described in Table 2, 40.4\% of sample household heads were illiterate. About $47.4 \%, 9.7 \%, 0.8 \%$, and $0.5 \%$ of the head attended basic, primary, secondary (grade 9 or 10), and preparatory or above level of education respectively. About $8 \%$ of sample households have a one-room house, while $48 \%$ and $44 \%$ of households have two rooms and three and above rooms house respectively.

Respondents were also asked to know their attitudes towards the solar home system. The analysis showed that $85.4 \%$ of respondents respectively had a favorable attitude, while $10 \%$ and $4.6 \%$ of respondents had a neutral and unfavorable attitude towards the solar home system.

\subsection{Reasons for using solar home system}

Table 3 summarizes why households tend to use SHS. Households who adopted SHS indicated the reasons why they had adopted it. Accordingly, about $25.9 \%$ of

\footnotetext{
${ }^{2}$ Tropical livestock unit (TLU): is a convenient unit for calculating all the animals in the herd. It is based on the live weight of a mature cow or beef type. The conversion factor for a herd of cattle is $0.7 \mathrm{LU}$ (FAO).
} 
Table 1. Description of explanatory variables and their expected effect on households' attitude towards the solar home system.

\begin{tabular}{llc}
\hline Variables & Description & Expected sign \\
\hline Gender of head & Dummy, $1=$ male, 0= female & \pm \\
Age of head & Continuous variable, year & \pm \\
Family size & Continuous variable, number & \pm \\
Off-farm income & Dummy, $1=$ If the household has off-farm income, $0=$ otherwise & + \\
Land & Continuous variable, number & + \\
Cattle(TLU) & Continuous variable, number & + \\
Credit & Dummy, $1=$ If household got access to credit, $0=$ otherwise & + \\
Phone & Dummy, $1=$ if the household has a cell phone, 0 if not & + \\
Media & Dummy, $1=$ if HH has media access, $0=$ otherwise & + \\
Training & Dummy, $1=$ If household got training, $0=$ otherwise & + \\
Log income & Continuous variable, Birr & + \\
Education & Dummy, $0=$ illiterate, $1=$ basic education, $2=$ primary education, & + \\
& $3=$ secondary education, $4=$ preparatory \& above & + \\
House & Dummy, $0=$ one room house, $1=$ two room house, $3=$ three \& above rooms house + \\
Kebele-dummy & Kebele dummy $(0=$ Michig, $1=$ Yelemelem, $2=$ Limichim, $3=$ Yegelaw $)$ & \pm \\
\hline
\end{tabular}

Table 2. Descriptive statistics of explanatory variables.

\begin{tabular}{lll}
\hline Variables & Mean & Std. Dev. \\
\hline Sex of head $(1=$ if male, $0=$ otherwise & 0.91 & 0.289 \\
Age of head (years) & 49.69 & 10.682 \\
Family size of the household & 4.91 & 1.498 \\
Off-farm income $(1=$ if HH participated in off-farm income $0=$ otherwise & 0.09 & 0.281 \\
Landholding size & 1.4874 & 0.74189 \\
Number of cattle (TLU) & 3.4113 & 1.99092 \\
Credit $(1=$ if HH has credit opportunity, $0=$ otherwise) & 0.96 & 0.184 \\
mobile phone access $(1=$ if the head has a mobile phone, $0=$ otherwise & 0.51 & 0.501 \\
media access $(1=$ if HH has media access, $0=$ otherwise & 0.82 & 0.385 \\
Training Accessibility $(1=$ if head got training, $0=$ otherwise $)$ & 0.55 & 0.498 \\
The annual income of the household & $80,171.7008$ & $38,092.30473$ \\
Illiterate $(1=$ if head is illiterate, $0=$ otherwise $)$ & 0.404 & 0.491 \\
Basic education $(1=$ if head attended basic education, $0=$ otherwise $)$ & 0.474 & 0.500 \\
Primary education $(1=$ if head attended primary education, $0=$ otherwise $)$ & 0.097 & 0.296 \\
Secondary education $(1=$ if head attended secondary education, $0=$ otherwise) & 0.008 & 0.090 \\
Preparatory \&above $(1=$ if head preparatory or above education, $0=$ otherwise $)$ & 0.005 & 0.073 \\
one-room house $(1=$ if HH has a one-room house, $0=$ otherwise $)$ & 0.08 & 0.273 \\
two-room house $(1=$ if HH has a two-room house, $0=$ otherwise & 0.48 & 0.506 \\
three \& above room house $(1=$ if HH has three \& above room house & 0.44 & 0.498 \\
Kebele dummy & 1.51 & 0.982
\end{tabular}

households indicated two reasons for how they adopted SHS, which are due to the cost-effectiveness of the technology and their environmental and health awareness. As shown in Table $3,21.1 \%$ of the adopted respondents confirmed two reasons why they adopted SHS, are in terms of reliable energy source and their environmental and health awareness. Furthermore, about $14.5 \%$ of households adopted the solar home system due to its reliable energy source. The other $12.7 \%$ of households adopted SHS because of the cost-effectiveness of the product. This confirmed a study conducted in Germany, stated that the economic feasibility of the residential solar photovoltaic system is the 
Table 3. Reasons for using solar home system.

\begin{tabular}{llrr}
\hline Reasons & No & $\%$ & $\mathrm{Chi}^{2}$ test $^{2}$ \\
\hline Cost-effectiveness & 29 & 12.7 \\
Reliable energy sources & 33 & 14.5 \\
Environmental and health awareness & 25 & 11.0 & \\
Cost-effectiveness and \& reliable energy source & 5 & 2.2 & 354.472 \\
Cost-effectiveness and environmental and health awareness & 59 & 25.9 & $(0.000)$ \\
Cost-effectiveness, reliable energy source, and environmental and health awareness & 29 & 12.7 & \\
Reliable energy source and environmental and health awareness & 48 & 21.1 \\
Total & 228 & 100.0 \\
\hline
\end{tabular}

Table 4. Reasons for ignoring solar home system (non-adopters).

\begin{tabular}{llrr}
\hline Reasons & No. & $\%$ & Chi $^{2}$ test \\
\hline Lack of awareness about solar energy technology & 43 & 30.1 & \\
Lack of credit accessibility & 1 & 0.7 & 354.58 \\
Unable to afford the cost & 32 & 22.4 & $(0.000)$ \\
Mal functioning of solar products & 15 & 10.5 & \\
because of another alternative & 14 & 9.8 \\
lack of awareness \& unable to afford the cost & 6 & 4.2 \\
Mal functioning of the product \& lack of attention to implementing the guarantee & 17 & 11.9 \\
Lack of solar product supply that the household need & 15 & 10.5 \\
Total & 143 & 100.0 \\
\hline
\end{tabular}

main determinant of successful adoption [44]. Moreover, $12.7 \%$ of households mentioned three reasons for their acceptance of SHS, which are due to cost-effectiveness, reliable energy source, and environmental and health awareness. Table 3 also shows that $11 \%$ of households adopted SHS because of their environmental and health awareness. About $2.2 \%$ of households adopted solar because of two reasons cost-effectiveness and reliable energy source; generally, the result revealed that most of the respondents perceived SHS as its cost-effectiveness and environmental and health awareness they acquired. This is consistent with the idea of previous literature, which suggested that the adoption of a residential solar photovoltaic system is socially accepted by environmental values [44].

Today, the costs of kerosene and battery/dry cell being used for sources of lighting in the most rural area of Ethiopia are getting higher and become beyond their financial capacity to afford its day-to-day expense. But those adopted households have no more expense regarding their home light after once they invest in solar in addition to its positive environmental and health impact. Discussion with key informants revealed that the improvement of community consciousness and a need for change to acquire better living conditions is one reason for adopting solar energy technology. Likewise, since most parts of the study area are off-grid where there is no electricity access still, many households considered solar energy as the only and the best way to solve their lighting problem. Furthermore, its environmental value is high. Because it substitutes other lighting energy sources that could affect the health of family members and the environment including the nonrechargeable dry cell that can be used as a lighting energy source and its remnant also pollutes the environment while dropped out after usage.

Solar energy technology is economically feasible than other energy sources as indicated by informants. For instance, if households use dry cell/battery as a source of light for their home, they have to buy dry cells within at least two weeks intervals. The cost to be incurred for it every two weeks is difficult for low-income families. But for those households who use solar energy technology, it is not required to cost more money than the ones they invest in it.

\subsection{Reason for rejecting solar home system}

About $30.1 \%$ of non-adopters didn't use SHS due to a lack of awareness about its use. This somewhat corresponds with Guta [22] and Anteneh [23], who revealed that most of the problems of rural Ethiopia are poverty and backwardness or lack of education to adopt new technologies. As shown in Table 4, 22.4\% of households didn't decide to use solar due to the lack of financial capacity to afford the cost. This result confirmed the previous study conducted in India that identified financial and economic factors as the biggest barriers to solar PV adoption [45]. Among the 
Table 5. Ordered logistic regression model of factors affecting households towards SHS.

\begin{tabular}{|c|c|c|c|c|c|c|}
\hline Variables & Coef. & Std. Err. & $\mathrm{z}$ & $\mathrm{p}>|\mathrm{z}|$ & \multicolumn{2}{|c|}{ [95\% Conf. Interval] } \\
\hline Gender & -1.195108 & .6737616 & -1.77 & 0.076 & -2.515657 & .1254404 \\
\hline Age & .0082668 & .0225285 & 0.37 & 0.714 & -.0358882 & .0524218 \\
\hline Family size & -.2135375 & .1520934 & -1.40 & 0.160 & -.5116351 & .08456 \\
\hline \multicolumn{7}{|l|}{ Edu_level } \\
\hline Basic educ. & -.1104768 & .4984921 & -0.22 & 0.825 & -1.087503 & .8665496 \\
\hline Primary educ. & -.371819 & 1.271208 & -0.29 & 0.770 & -2.86334 & 2.119702 \\
\hline Secondary educ & 11.39541 & 5121.075 & 0.00 & 0.998 & -10025.73 & 10048.52 \\
\hline Preparatory \& above & 16.18215 & 4134.714 & 0.00 & 0.997 & -8087.707 & 8120.072 \\
\hline Off-farm income & 14.78547 & 1245.719 & 0.01 & 0.991 & -2426.779 & 2456.35 \\
\hline log income & 1.446666 & .5877465 & 2.46 & 0.014 & .2947041 & 2.598628 \\
\hline Landholding size & -.4105679 & .3754946 & -1.09 & 0.274 & -1.146524 & .325388 \\
\hline Cattle (TLU) & .355805 & .2121917 & 1.68 & 0.094 & -.060083 & .7716931 \\
\hline Credit & -.1964197 & .7691013 & -0.26 & 0.798 & -1.703831 & 1.310991 \\
\hline \multicolumn{7}{|l|}{ House type } \\
\hline Two rooms house & -.4454815 & .6398431 & -0.70 & 0.486 & -1.699551 & .808588 \\
\hline Three \& above rooms house & .2837139 & 1.03432 & 0.27 & 0.784 & -1.743516 & 2.310944 \\
\hline Mobile phone access & 1.517451 & .7023499 & 2.16 & 0.031 & .1408701 & 2.894031 \\
\hline Media access & 1.568035 & .5444793 & 2.88 & 0.004 & .5008749 & 2.635195 \\
\hline Training access & 1.421966 & .5627334 & 2.53 & 0.012 & .3190287 & 2.524903 \\
\hline Kebele dummy & yes & & & & & \\
\hline Log-likelihood & $=-96.683426$ & & & & & \\
\hline LR $\operatorname{chi} 2(20)$ & $=0.4845$ & & & & & \\
\hline Number of obs & $=371$ & & & & & \\
\hline
\end{tabular}

non-adopted households, $11.9 \%$ were due to both malfunctioning of the solar product they saw and heard from others and lack of attention of solar product distributors to implement the guarantee signed. The remaining $10.5 \%$ were due to a lack of solar product supply that the households could afford. About $10.5 \%$ did not adopt due to the information they obtained from peer adopters that SHS is malfunctioning. Table 4 also shows that $9.8 \%$ of households were none adopted due to their tendency to use other alternative energy sources that could substitute solar. The other $4.2 \%$ of non-adopted households were due to two reasons, which are lack of awareness and unable to afford the cost of solar products. Moreover, $0.7 \%$ (one respondent) was due to lack of credit accessibility, Therefore, the result indicated that as compared to other factors, lack of awareness about solar energy technology and unable to afford the cost were the major problem of most of the households to adopt the solar home system. The third most important problem was the malfunction of the product and lack of attention to implementing guarantees signed between households and solar product distributors when the product fails to function. This situation leads households to reject the adoption or discontinuation with the technology.

Furthermore, there are governmental and institutional factors affecting the adoption of the solar home system in the study area as indicated by key informants. One of the factors was the lack of quality assurance of solar energy technologies products by the government body before they have been allowed to be distributed to the user/customer. Most of the time solar products are passed by cheating without being checked their quality. Therefore due to the lack of attention of the government and strong chine from top to bottom to control the distribution and quality of solar products, most products fail within a short period after distribution. This result corresponds with TERI [46], which revealed that due to low quality and nonexistent distributors after-sale services, it often builds distrusts within households when the products are broken down after a short period of usage.

\subsection{Econometrics result}

Tables 5 and 6 presents the results of the ordered logit model and marginal effect respectively. The result of maximum likelihood estimation in Table 5 reveals that of thirteen explanatory variables, four are statistically significant at $5 \%$, while two are significant at $10 \%$. The signs of explanatory variables are interpreted concerning the bases or reference category. The log-likelihood for the fitted model was -96.683426 and the log-likelihood value $(\mathrm{LR}=181.77)$ indicates that all parameters are jointly statistically significant at 5\%, in explaining households' attitudes towards SHS. The kebele dummies were also controlled in the model. 
Table 6. Marginal effect of the ordered logistic regression model of factors affecting households' attitude towards SHS.

\begin{tabular}{|c|c|c|c|c|c|c|}
\hline \multirow[t]{2}{*}{ Attitude } & \multicolumn{6}{|c|}{ Delta-method } \\
\hline & $\mathrm{dy} / \mathrm{dx}$ & Std. Err. & $\mathrm{Z}$ & $\mathrm{P}>|\mathrm{z}|$ & {$[95 \% \mathrm{Cc}$} & nterval] \\
\hline \multicolumn{7}{|l|}{ Gender } \\
\hline Unfavorable & .0262719 & .0124464 & 2.11 & 0.035 & .0018774 & .0506664 \\
\hline Neutral & .0323624 & .0168341 & 1.92 & 0.055 & -.0006319 & .0653567 \\
\hline Favorable & -.0586343 & .0281968 & -2.08 & 0.038 & -.1138989 & -.0033697 \\
\hline \multicolumn{7}{|l|}{ Age } \\
\hline Unfavorable & -.0002165 & .0005879 & -0.37 & 0.713 & -.0013688 & .0009358 \\
\hline Neutral & -.000251 & .0006887 & -0.36 & 0.716 & -.0016008 & .0010989 \\
\hline Favorable & .0004675 & .0012749 & 0.37 & 0.714 & -.0020313 & .0029663 \\
\hline \multicolumn{7}{|l|}{ Family size } \\
\hline Unfavorable & .0055926 & .003927 & 1.42 & 0.154 & -.0021042 & .0132894 \\
\hline Neutral & .0064828 & .0048054 & 1.35 & 0.177 & -.0029357 & .0159012 \\
\hline Favorable & -.0120754 & .0085659 & -1.41 & 0.159 & -.0288642 & .0047134 \\
\hline \multicolumn{7}{|l|}{ Edu_basic } \\
\hline Unfavorable & .0029135 & .0132274 & 0.22 & 0.826 & -.0230117 & .0288387 \\
\hline Neutral & .0033574 & .0150553 & 0.22 & 0.824 & -.0261505 & .0328652 \\
\hline Favorable & -.0062708 & .0282686 & -0.22 & 0.824 & -.0616763 & .0491346 \\
\hline \multicolumn{7}{|l|}{ Edu_prim. } \\
\hline Unfavorable & .0103405 & .0376261 & 0.27 & 0.783 & -.0634053 & .0840862 \\
\hline Neutral & .0114322 & .0389946 & 0.29 & 0.769 & -.0649959 & 0878603 \\
\hline Favorable & -.0217727 & .0765566 & -0.28 & 0.776 & -.1718208 & 0878603 \\
\hline \multicolumn{7}{|l|}{ Edu_sec. } \\
\hline Unfavorable & -.0424963 & .0107946 & -3.94 & 0.000 & -.0636534 & -.0213392 \\
\hline Neutral & -.1011645 & .0636667 & -1.59 & 0.112 & -.2259489 & .0236199 \\
\hline Favorable & .1436608 & .0695167 & 2.07 & 0.039 & .0074106 & .2799109 \\
\hline \multicolumn{7}{|c|}{ edu_pre \&ab. } \\
\hline Unfavorable & -.0424974 & .0092922 & -4.57 & 0.000 & -.0607097 & -.0242851 \\
\hline Neutral & -.1011764 & .0150097 & -6.74 & 0.000 & -.130595 & -.0717579 \\
\hline Favorable & .1436738 & .0171573 & 8.37 & 0.000 & .1100462 & .1773015 \\
\hline \multicolumn{7}{|c|}{ Off-farm inc } \\
\hline Unfavorable & -.0438532 & .0082536 & -5.31 & 0.000 & -.06003 & -.0276765 \\
\hline Neutral & -.1056937 & .0139105 & -7.60 & 0.000 & -.1329578 & -.0784297 \\
\hline Favorable & .1495469 & .0132567 & 11.28 & 0.000 & .1235644 & .1755295 \\
\hline \multicolumn{7}{|l|}{ Log income } \\
\hline Unfavorable & -.0378886 & .0148485 & -2.55 & 0.011 & -.0669911 & -.0087861 \\
\hline Neutral & -.0439191 & .0198473 & -2.21 & 0.027 & -.0828191 & -.0050192 \\
\hline Favorable & .0818077 & .0327869 & 2.50 & 0.013 & .0175465 & .1460689 \\
\hline \multicolumn{7}{|c|}{ Landholding size } \\
\hline Unfavorable & .0107529 & .0096985 & 1.11 & 0.268 & -.0082558 & .0297615 \\
\hline Neutral & .0124644 & .0118811 & 1.05 & 0.294 & -.0108221 & .0357508 \\
\hline Favorable & -.0232173 & .0213347 & -1.09 & 0.276 & -.0650326 & .018598 \\
\hline \multicolumn{7}{|c|}{ Cattle(TLU) } \\
\hline Unfavorable & -.0093186 & .0056362 & -1.65 & 0.098 & -.0203655 & .0017282 \\
\hline Neutral & -.0108018 & .0064799 & -1.67 & 0.096 & -.0235021 & .0018985 \\
\hline Favorable & .0201205 & .0117749 & 1.71 & 0.087 & -.0029579 & .0431988 \\
\hline \multicolumn{7}{|l|}{ Credit } \\
\hline Unfavorable & .0049656 & .0188156 & 0.26 & 0.792 & -.0319124 & .0418436 \\
\hline Neutral & .0058263 & .0222342 & 0.26 & 0.793 & -.0377519 & .0494045 \\
\hline
\end{tabular}


Table 6. (continued).

\begin{tabular}{|c|c|c|c|c|c|c|}
\hline \multirow{3}{*}{$\begin{array}{l}\text { Attitude } \\
\text { Favorable }\end{array}$} & \multicolumn{6}{|c|}{ Delta-method } \\
\hline & \multirow{2}{*}{$\frac{\mathrm{dy} / \mathrm{dx}}{-.0107919}$} & \multirow{2}{*}{$\frac{\text { Std. Err. }}{.0410219}$} & \multirow{2}{*}{$\frac{\mathrm{Z}}{-0.26}$} & \multirow{2}{*}{$\frac{\mathrm{P}>|\mathrm{z}|}{0.792}$} & \multicolumn{2}{|c|}{ [95\% Conf. Interval] } \\
\hline & & & & & -.0911934 & .0696097 \\
\hline \multicolumn{7}{|c|}{ 2rooms house type } \\
\hline Unfavorable & .0112208 & .0151775 & 0.74 & 0.460 & -.0185266 & .0409681 \\
\hline Neutral & .014484 & .0192324 & 0.75 & 0.451 & -.0232107 & .0521787 \\
\hline Favorable & -.0257048 & .0342318 & -0.75 & 0.453 & -.0927979 & .0413884 \\
\hline \multicolumn{7}{|c|}{3 \& above rooms house } \\
\hline Unfavorable & -.0061035 & .0219724 & -0.28 & 0.781 & -.0491685 & .0369616 \\
\hline Neutral & -.0086819 & .0326064 & -0.27 & 0.790 & -.0725893 & .0552256 \\
\hline Favorable & .0147853 & .0545422 & 0.27 & 0.786 & -.0921155 & .1216862 \\
\hline \multicolumn{7}{|c|}{ Mobile phone access } \\
\hline Unfavorable & -.0301092 & .0109655 & -2.75 & 0.006 & -.0516012 & -.0086172 \\
\hline Neutral & -.0548516 & .0270374 & -2.03 & 0.042 & -.1078439 & -.0018593 \\
\hline Favorable & .0849608 & .0362666 & 2.34 & 0.019 & .0138796 & .1560419 \\
\hline \multicolumn{7}{|l|}{ Media access } \\
\hline Unfavorable & -.041571 & .0158979 & -2.61 & 0.009 & -.0727304 & -.0104117 \\
\hline Neutral & -.0688009 & .0318188 & -2.16 & 0.031 & -.1311646 & -.0064372 \\
\hline Favorable & .1103719 & .0450577 & 2.45 & 0.014 & .0220604 & .1986835 \\
\hline \multicolumn{7}{|l|}{ Training access } \\
\hline Unfavorable & -.0311663 & .0106982 & -2.91 & 0.004 & -.0521344 & -.0101981 \\
\hline Neutral & -.0507649 & .0224822 & -2.26 & 0.024 & -.0948293 & -.0067005 \\
\hline Favorable & .0819312 & .0312762 & 2.62 & 0.009 & .0206309 & .1432314 \\
\hline kebele dummy & yes & & & & & \\
\hline
\end{tabular}

\subsubsection{Gender of the household head}

The gender of the household's head was found to be one of the key determinants of attitude towards the solar home system. The estimated result indicates that the gender of households' heads was found to be statistically significant $(P<0.1)$ and negatively associated with the attitude of households towards SHS. The marginal outcome in Table 6 indicated that the attitude of being the male household head is $2.6 \%$ and $3.2 \%$ more likely to be in the unfavorable and neutral attitude category respectively. Households headed by a male individual are $5.9 \%$ less likely to have a favorable attitude towards SHS. The result contradicts past studies [47], which found that males have greater interest and knowledge towards technology than female counterparts. Moreover, the credible explanation for the negative association of gender towards SHS is that women are more responsible and highly attached to household energy use in developing countries [22,48].

\subsubsection{Household income}

Income is one of the key factors affecting households' attitudes towards SHS. It is found to be statistically significant $(P<0.05)$ and positively associated with the attitude of households towards SHS. The marginal effect in Table 6 shows that if income increased by one Birr, the households' attitude is $3.8 \%$ less likely to be in the unfavorable attitude category, $4.4 \%$ less likely to be in the neutral category, and
$8.2 \%$ more likely to be in favorable attitude category. The result corroborates with a previous study [49], which revealed that the income of households positively influences their attitude to alter their energy source to green ones.

\subsubsection{Number of cattle}

The number of cattle (measured in tropical livestock units) owned by households has been found to positively influence the attitude of households towards SHS at a statistically significant level $(P<0.1)$. The result of the marginal effect shows that as the number of cattle increased by one unit, the household is $0.9 \%$ less likely to be in the unfavorable attitude category, $1.1 \%$ less likely to be in the neutral attitude category, and $2 \%$ more likely to be in the favorable attitude category. Since the number of cattle is one of the key assets of households in rural Ethiopia, the positive effect might be related to that households having a large number of cattle are financially strong, leading them to have an interest in using SHS. The result of this study is consistent with past literature [35], which stated that assets have a positive effect on people's attitudes regarding future confidence and expectation to undertake a specific plan.

\subsubsection{Mobile phone access}

Mobile access is found to be statistically significant $(P<0.05)$ and positively affect households' attitudes towards SHS. 


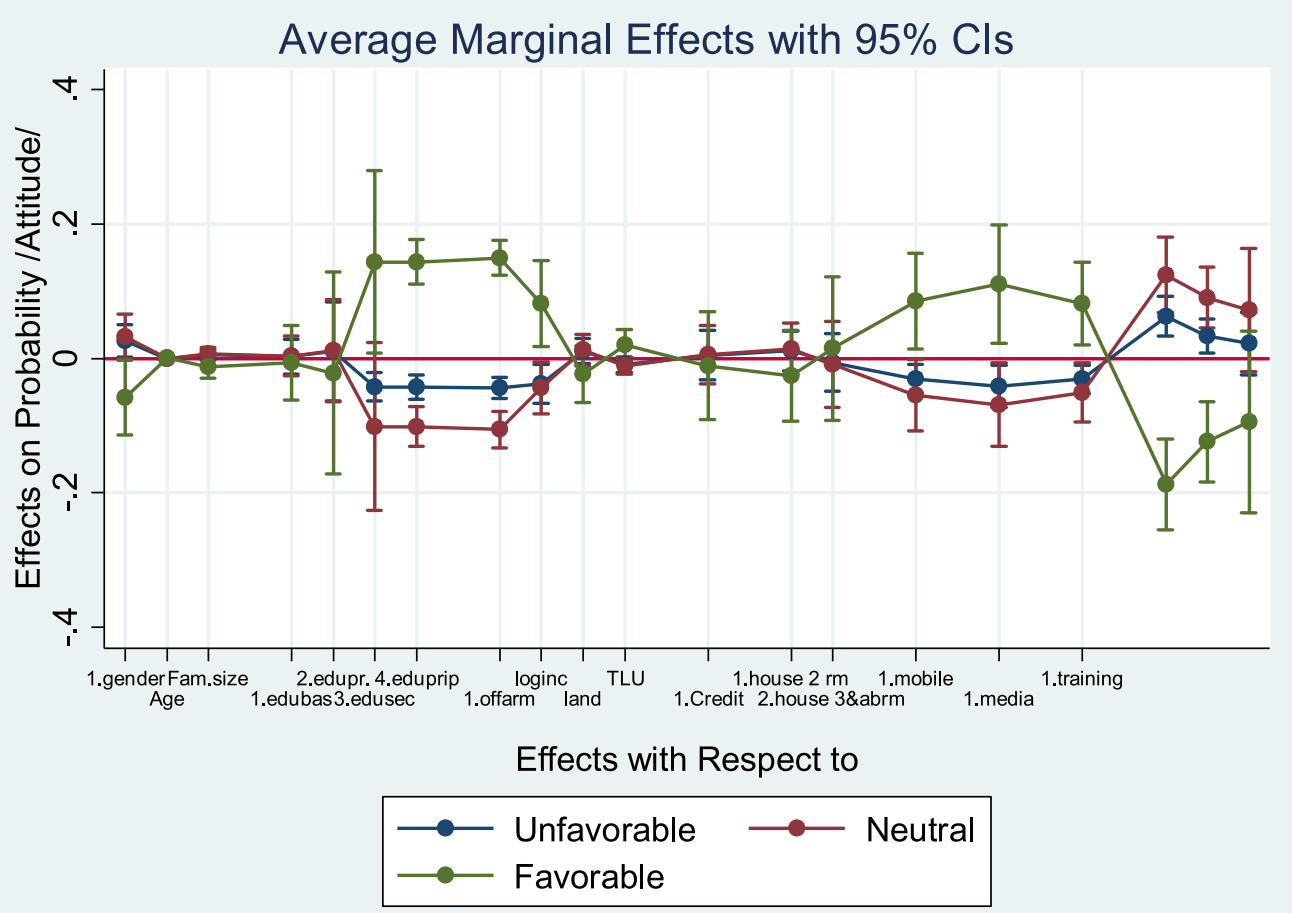

Fig. 4. Average marginal effect of explanatory variables (Ordered logistic regression output computed in 2020).

As shown in Table 6 the result of the marginal effect indicates that a household having a mobile cell phone is $3 \%$ and $5.5 \%$ less likely to be in the unfavorable and neutral attitude category respectively, while $8.5 \%$ more likely to be in the favorable attitude category towards SHS. As affirmed by previous literature, the mobile phone has a relevant role in the improvement of households' attitudes towards solar technology [50]. Moreover, the finding also agrees with the other literature, which revealed that households who have a cell phone have an opportunity to get more knowledge and awareness about new technologies including SHS, which leads them to develop a positive attitude towards it [24].

\subsubsection{Media access}

Media appears to be one of the key factors influencing households' attitudes towards SHS. The result shows that media has a significant $(P<0.05)$ and positive effect on households' attitudes towards SHS. The marginal effect in Table 6 shows that being accessed with media is $4.2 \%$ and $6.9 \%$ less likely to be in the unfavorable and neutral attitude category respectively and $11 \%$ more likely to be in the favorable attitude category. The finding agrees with previous literature, for instance, Zeru and Guta [24] and Abera [51] argued that media assists to get immense information and knowledge about something that happened and produced daily including new technologies that could bring attitude change. Moreover, it is also related to the other literature which elucidated that TV and radio are important media types through which to bring an attitudinal change towards modern technologies including solar $[50,52]$.

\subsubsection{Training}

Training regarding SHS plays an important role in changing the attitude of households. Thus, it is a key factor in influencing households' attitudes towards SHS. The training was found to have a positive and significant $(P<0.05)$ effect on households' attitudes. The result of the marginal effect shows that households who got training access are $3 \%$ and $5 \%$ less likely to be in the unfavorable and neutral attitude category and $8 \%$ more likely to be in the favorable attitude category regarding SHS. The result of this study corroborates with Mills and Harris [53], who suggested that providing training to users is an effective tool for overcoming resistance to new technology and enhance their willingness to adopt. Moreover, the result confirms the idea of previous literature [54], which stated that adequate training regarding renewable energy technologies or awareness-raising activities are key to develop the local knowledge required for effective and sustainable use of renewable energy technologies.

\section{Conclusion and policy implications}

Lack of awareness and poor attitude towards SHS highly affects the households' motivation to use it and also leads them unable to understand its difference from a variety of detrimental energy sources that could cause health hazards 
in off-grid areas of many developing countries. However, many of the previous studies conducted on solar energy technology in Ethiopia as well as abroad lack exploring the underlying factors influencing households' attitudes towards SHS. Investigation of factors affecting households' attitudes towards SHS has paramount importance to take considerable action accordingly. To fill the observed gap, the study used 228 adopters and 143 non-adopters as a source of data from four kebeles of Baso Liben district, the Amhara region of northern Ethiopia. Out of the total sample households, $61.5 \%$ were SHS adopters. Households depicted some reasons why they adopt SHS. These were cost-effectiveness, reliable source of energy, and their environmental and health awareness. Many households adopted SHS due to the above reasons. On the other hand, non adopted households refrained from using SHS due to lack of awareness, the low financial capacity to afford the cost, malfunctioning of the product, alternative energy source, lack of attention of distributors to implement guarantee term, and lack of supply of affordable solar products.

The ordered logit model was employed to estimate factors affecting households' attitudes towards SHS. The finding reveals that the male-headed households were $2.6 \%$ and $3.2 \%$ more likely to have unfavorable and neutral attitudes respectively and $5.9 \%$ less likely favorable attitudes towards SHS. Wealth variables (income and number of cattle) were found to have a positive effect on attitude towards SHS. As the income of the households increase by one birr, $8.2 \%$ more likely they have a favorable attitude, and $3.8 \%$ and $4.4 \%$ less likely they have an unfavorable and neutral attitude towards SHS respectively. Likewise, as the number of households' cattle increase, $2 \%$ more likely they have a favorable attitude, and $0.9 \%$ and $1.1 \%$ less likely they have an unfavorable and neutral attitude towards SHS respectively. This implies that improving rural households' economic status helps to bring an attitudinal change towards using SHS. Similarly, households who have a cell phone access are $3 \%$ and $5.5 \%$ less likely to be in the unfavorable and neutral attitude category respectively and $8.5 \%$ more likely to be in the favorable attitude category towards SHS. Likewise being accessed with media is $4.2 \%$ and $6.9 \%$ less likely they have unfavorable and neutral attitudes respectively, and $11 \%$ more likely they have a favorable attitude towards SHS. This entails that better media availability of rural households is crucial in providing new information about new technologies including SHS and the other renewables that could raise their awareness level. Moreover, households who attained training regarding SHS are $3 \%$ and $5 \%$ less likely they have an unfavorable and neutral attitude, while $8 \%$ more likely they have a favorable attitude towards SHS. Thus, enhancing households' awareness about the benefit and utilization of SHS might bring an attitudinal change of rural households towards SHS.

\section{References}

1. IEA, World Energy Outlook and-projections/access-toelectricity, 2019, https://www.iea.org/reports/sdg7-data
2. A.W. Bhutto, A.A. Bazmi, G. Zahedi, Greener energy: issues and challenges for Pakistan-solar energy prospective, Renew. Sustain. Energy Rev. 16, 2762-2780 (2012)

3. J. Ondraczek, Are we there yet? Improving solar PV economics and power planning in developing countries: the case of Kenya, Renew. Sustain. Energy Rev. 604-615 (2014)

4. R.A. Cabaraal, D.F. Barnes, S.G. Agarwal, Productive use of energy for rural development, Annu. Rev. Environ. Resour. 30, 117-144 (2005)

5. D.D. Guta, Determinants of household use of energy-efficient and renewable energy technologies in rural Ethiopia, Technol. Soc. 61, 101249 (2020)

6. IRENA, More people have access to electricity, but world is falling short of sustainable energy goal (2019), https://www. who.int/news-room/detail/21-05-2019-more-people-have-ac cess-to-electricity-than-ever-before-but-world-is-fallingshort-of-sustainable-energy-goals

7. S. Komatsu, S. Kaneko, P.P. Ghosh, A. Morinaga, Determinants of user satisfaction with solar home systems in rural Bangladesh, Energy 61, 52-58 (2013)

8. J. Karp, Managing the Risks of Renewable Energy Projects in Developing Countries (2016) http://blog.sandw.com/ener gyfinancereport/2015/05/managing-the-risks-of-renewableenergy-projects-in-developing-countries/

9. P. Kotler, Understanding the Marketing Management; Marketing Management, Pearson Education, United Kingdom, 2003, 11th edn., pp. 5-8

10. B. Yadav, S. Yadav, L. Yadav, Perception, and attitude of rural women towards solar cooker, Indian Res. J. Extens. Educ. 9, 22-24 (2009)

11. F. Sultan, R. Winer, Time preferences for products and attributes and the adoption of technology-driven consumer durable innovations, J. Econ. Psychol. 14, 587-613 (1993)

12. S. Auty, R. Elliott, Fashion involvement, self-monitoring and the meaning of brands, J. Product Brand Manag. 7, 109-123 (1998)

13. A. Faiers, C. Neame, Consumer attitudes towards domestic solar power systems, Energy Policy 1797-1806 (2006)

14. Y. Sun, S. Spincer, Exploring residents' attitudes toward solar photovoltaic system adoption in China, Undergraduate Rev. 12, 148-160 (2016)

15. R.C. Thsaur, Y. Lin, Exploring the consumer attitude of building-attached photovoltaic equipment using revised technology acceptance model, Sustainability 4177 (2018)

16. K. Alrashoud, K. Tokimatsu, Factors Influencing Social Perception of Residential Solar Photovoltaic Systems in Saudi Arabia, Sustainability 11, 5259 (2019)

17. Y.O. Adepoju, Factors influencing willingness to adopt renewable energy technologies among micro and small enterprises in Lagos State Nigeria, Int. J. Sustain. Energy Plan. Manag. 19, 69-78 (2019)

18. I. Gitone, Determinants of Adoption of Renewable Energy in Kenya, 2014, https://www.seemanticscholar.org

19. I. Keriri, Factors Influencing Adoption of Solar Technology in Lakipia North constituency, Kenya, 2013, http:// erepository.uonbi.ac.ke/bitstream/handle/11295/56297/ker iri_FactorsinfluencingadoptionofSolartechnology.pdf?se quence $=5$

20. N. Naomi, Factors affecting the adoption of solar power for domestic usage in Kajiado country kenya. Masters thesis, 2014, http://erepository.uonbi.ac.ke/bitstream/hand/e/ 11295/74308/N'geno_Factors affecting the adoption ofsolar 
power for domestic usage in kajiado country.pdf?sequence $=1$.

21. E. Mekuria, Challenges and Prospects of Solar Home System Dissemination in Rural Parts of Ethiopia, 2016, http:// localhots:80/xmlui/handle/123456789/13346

22. D. Guta, Determinants of household adoption of solar energy technology in rural Ethiopia, J. Clean. Product. (2018) doi: 10.1016/j.jclepro.2018.09.016

23. C. Anteneh, The Determinants of Households' Adoption of Solar Energy in Rural Ethiopia: The case study of Gurage Zone, 2019, Available at: http://localhost:80/xmlui/handle/ $123456789 / 18658$

24. A.M. Zeru, D. Guta, Factors Influencing Household Adoption of Solar Home System in Baso Liben District, Amhara Regional State of Ethiopia, 2020, Available at: https://doi.org/10.21203/rs.3.rs-60920/v1

25. M.A. Fishbein, Belief, Attitude, Intention, and Behavior: An Introduction to Theory and Research, 1975

26. D.E. Ajzen, Intention, perceived control, and weight loss: an application of the theory of plannedbehavior, University of Massachusetts at Amherst, J. Person. Soc. Psychol. 49, 844-849 (1985)

27. M. Fishbein, J.N. Joseph Cappella, The role of theory in developing effective health communications, J. Commun. 56, S1-S17 (2006)

28. E. Rogers, Diffusion of Innovations, The Free Press, New York, 1995, Available at: https://www.researchgate.net

29. E.M. Rogers, Diffusion of Innovations, 5th edn. Free Press, New York, 2003

30. W. Legesse, Determinants of adoption of renewable energy sources towards reducing deforestation in Ambo District, West Shoa, Oromia Regional State, Ethiopia, J. Energy Technolog. Policy 6, 27-33 (2016)

31. B. Bollinger, K. Gillingham, Peer effects in the diffusion of solar photovoltaic panels, Market. Sci. 31, 900-912 (2012)

32. N.M.A. Huijts, E.J.E. Molin, L. Steg, Psychological factors influencing sustainable energy technology acceptance: a review-based comprehensive framework, Renew. Sustain. Energy Rev. 16, 525-531 (2012)

33. S. Chen, F. Chen, The path choice of cultivating the new generation private entrepreneurs, Lilun Daobao 12, 31-32 (2013)

34. N. Wamukonya, Power sector reform in developing countries: Mismatched agendas, Energy Policy 31, 1273-1289 (2003)

35. G. Yadama, M. Sherraden, Effect of assets on attitudes and behaviors: advance test of a social policy proposal, Social Work Res. 20, 3-11 (1996)

36. A.M. Kaplan, M. Haenlein, Users of the world, unite! the challenges and opportunities of social media, Bus. Horizons 53, 59-68 (2010)

37. S.W. Edison, G.L. Geissler, Measuring attitudes towards general technology: Antecedents, hypotheses, and scale development, J. Target. Measur. Anal. Mark. 12, 137-156 (2003)

38. R. Coe, Analyzing ranking and rating data from participatory on-farm trials. In M.R. Bellon \& J. Reeves (Eds.), Quantitative Analysis of Data from Participatory Methods in Plant Breeding, CIMMYT, Mexico, D.F. (2002) pp. 44-65.
39. P. Sentas, L. Angelis, I. Stamelos, G. Bleris, Software productivity and effort prediction with ordinal regression, J. Inf. Softw. Technol. 47, 17-29 (2005)

40. M.P. Oluoch, P.A. Odundo, J.K. Mwanji, Context of Vignettes and Ethical Sensitivity in Decision-Making Among Undergraduate Business Studies Learners at University of Nairobi, Kenya. J. Educ. Learn. 9, 151-169 (2020)

41. B. Hagen, D. Pijawka, Public perceptions and support of renewable energy in North America in the context of global climate change, J. Disaster Risk Sci. 6, 385-398 (2015)

42. S. Karytsas, O. Polyzou, D. Mendrinos, C. Karystas, Towards social acceptance of geothermal energy power plants, Conference paper, 2019, Available at: https://www. researchgate.net/publication/333974365

43. A.C. Cameron, P.K. Trivedi, Micro econometrics: Methods and Applications, Cambridge University Press, 2005

44. S. Jacobsson, V. Lauber, The politics and policy of energy system transformation: explaining the German diffusion of renewable energy technology, Energy Policy 34, 256-275 (2006)

45. M.A. Eltawil, Z. Zhao, Grid connected photovoltaic power systems: technical and potential problems - a review, Renew. Sustain. Energy Rev. 14, 112-129 (2010)

46. TERI, Dissemination of solar Energy Technoogies in Ethiopia: successes, challenges and opportunities. National workshop, The Energy and Resources Institute (TERI), Addis Ababa, 2014, pp. 8-10

47. A.E. Bame, W.E. Dugger Jr., M. de Vries, J. McBee, Pupils' attitudes toward technology - PATT-USA, J. Technol. Stud. 19, 40-48 (1993)

48. R. Heltberg, Fuel switching: evidence from eight developing countries, Energy Econ. 26, 869-887 (2004)

49. B. Vand, A. Hast, S. Bozorg, Z. Li, S. Syri, S. Deng, Consumers' attitudes to support green energy: a case study in Shanghai. Energies (2019), Available at: https://www. researchgate.net/publication/333904415

50. M.A. Harun, The role of solar home system (SHS) in socioeconomic development of Bangladesh (2015), Available at: https://core.ac.uk/download/pdf/61807642.pdf

51. Y. Abera, K. Fenta, Determinants of lighting energy transitions in rural Ethiopia: lessons from Mida Oromo and Wonisho Districts of Ethiopia, Environ. Manag. Sustain. Dev. (2019) doi:10.5296emsdv8i315151

52. R. Gibbons, Exploring consumer perception and attitudes towards renewable energywith a view to developing best practice for marketing renewable energy. (2009), https:// research.thea.ie/bitstream/handle/20.500.12065/1153/Ex ploring \%20consumer\%20perception \%20and\%20attitudes\% 20towards\%20renewable\%20energy.pdf?sequence $=1 \&$ is Al lowed $=\mathrm{y}$

53. R.J. Mills, M.E. Harris, Alignment between technology acceptance and instructional design via self efficacy, Rev. Bus. Inf. Syst. 23, 7-16 (2019)

54. UN, Renewable Energy Technologies for Rural Development. UNCTAD Current Studies on Science, Technology and Innovation (2010), http://www.unctad.org/en/docs/ dtlstict20094_en.pdf

Cite this article as: Asmare Mossie Zeru, Dawit Diriba Guta, Factors influencing rural household attitude towards solar home system in Ethiopia, Renew. Energy Environ. Sustain. 6, 42 (2021) 